\title{
Warming resistant corals from the Gulf of Aqaba live close to their cold-water bleaching threshold
}

\author{
Jessica Bellworthy ${ }^{\text {Corresp., 1, } 2}$, Maoz Fine ${ }^{1,2}$ \\ ${ }^{1}$ The Goodman Faculty of Life Sciences, Bar Ilan University, Ramat Gan, Israel \\ 2 The Interuniversity Institute for Marine Sciences in Eilat, Eilat, Israel \\ Corresponding Author: Jessica Bellworthy \\ Email address: jhbellworthy@gmail.com
}

Global climate change is causing increasing variability and extremes in weather worldwide, a trend set to continue. In recent decades both anomalously warm and cold seawater temperatures have resulted in mass coral bleaching events. Whilst corals' response to elevated temperature has justifiably attracted substantial research interest, coral physiology under cold water stress is relatively unfamiliar. The response to below typical winter water temperature was tested for two common reef building species from the Gulf of Aqaba in an ex situ experiment. Stylophora pistillata and Acropora eurystoma were exposed to 1 or $3^{\circ} \mathrm{C}$ below average winter temperature and a suite of physiological parameters were assessed. At $3^{\circ} \mathrm{C}$ below winter minima (ca. $18.6^{\circ} \mathrm{C}$ ), both species had significant declines in photosynthetic indices (maximum quantum yield, electron transport rate, saturation irradiance, and photochemical efficiency) and chlorophyll concentration compared to corals at ambient winter temperatures. It was previously unknown that corals at this site live close to their cold-water bleaching threshold and may be vulnerable as climate variability increases in magnitude. In order to determine if a cold winter reduces the known heat resistance of this population, the corals were subsequently exposed to an acute warm period at $30^{\circ} \mathrm{C}$ the following summer. Exposed to above typical summer temperatures, both species showed fewer physiological deviations compared to the coldwater stress. Therefore, the cold winter experience did not increase corals' susceptibility to above ambient summer temperatures. This study provides further support for the selection of heat tolerant genotypes colonising the Red Sea basin and thereby support the mechanism behind the Reef Refuge Hypothesis. 
1 Warming resistant corals from the Gulf of Aqaba live close to their cold-water bleaching 2 threshold

3

4 Jessica Bellworthy ${ }^{1,2^{*}}$, Maoz Fine ${ }^{1,2}$

5 1. The Goodman Faculty of Life Sciences, Bar Ilan University, Ramat Gan, Israel

6 2. The Interuniversity Institute for Marine Sciences in Eilat, Eilat, Israel

7

$8 \quad$ Corresponding author: J. Bellworthy, Email: jhbellworthy@gmail.com

$9 \quad *$ Current address: Leon H. Charney School of Marine Sciences, Mount Carmel, Haifa, Israel

10

11

12

13

14

15 Keywords: Acropora eurystoma, coral physiology, photosynthesis, Red Sea, Stylophora

16 pistillata, symbiont 


\section{Abstract}

Global climate change is causing increasing variability and extremes in weather worldwide, a trend set to continue. In recent decades both anomalously warm and cold seawater temperatures have resulted in mass coral bleaching events. Whilst corals' response to elevated temperature has justifiably attracted substantial research interest, coral physiology under cold water stress is relatively unfamiliar. The response to below typical winter water temperature was tested for two common reef building species from the Gulf of Aqaba in an ex situ experiment. Stylophora pistillata and Acropora eurystoma were exposed to 1 or $3^{\circ} \mathrm{C}$ below average winter temperature and a suite of physiological parameters were assessed. At $3^{\circ} \mathrm{C}$ below winter minima (ca. $18.6^{\circ} \mathrm{C}$ ), both species had significant declines in photosynthetic indices (maximum quantum yield, electron transport rate, saturation irradiance, and photochemical efficiency) and chlorophyll concentration compared to corals at ambient winter temperatures. It was previously unknown that corals at this site live close to their cold-water bleaching threshold and may be vulnerable as climate variability increases in magnitude. In order to determine if a cold winter reduces the known heat resistance of this population, the corals were subsequently exposed to an acute warm period at $30^{\circ} \mathrm{C}$ the following summer. Exposed to above typical summer temperatures, both species showed fewer physiological deviations compared to the cold-water stress. Therefore, the cold winter experience did not increase corals' susceptibility to above ambient summer temperatures. This study provides further support for the selection of heat tolerant genotypes colonising the Red Sea basin and thereby support the mechanism behind the Reef Refuge Hypothesis. 


\section{Introduction}

41

42

Coral reefs form within defined environmental boundaries (Kleypas, Mcmanusi \& Menez, 1999). Reef building corals are mostly limited to the tropics as low winter water temperature limits the expansion of coral reefs to higher latitudes (Higuchi et al., 2015; Nakabayashi et al., 2019). Dana (1843) first suggested $19^{\circ} \mathrm{C}$ to be the lower temperature limiting the distribution of coral reefs. Later field and lab observations lowered this absolute value to $18^{\circ} \mathrm{C}$ (Vaughan $\&$ Wells, 1943), $16^{\circ} \mathrm{C}$ (Kleypas, Mcmanusi \& Menez, 1999), or $14^{\circ} \mathrm{C}$ (Mayor, 1914).

Ocean warming is considered the main cause of recurrent mass coral bleaching events and the recent decline of coral reefs worldwide (Hoegh-Guldberg \& Poloczanska, 2017). Coral bleaching is a potentially fatal reduction in the number of algal symbionts and/or the photosynthetic pigment chlorophyll following anomalous water temperature or light levels. Cold water bleaching is much less frequently reported (but see e.g. (Hoegh-Guldberg \& Fine, 2004; Lirman et al., 2011; Kemp et al., 2011; Zapata, Jaramillo-González \& Navas-Camacho, 2011)). Fewer studies have been conducted on the effect of cold-water stress in corals although global anthropogenic climate change has and will continue to produce more extreme weather events with increased variability (Urban, Cole \& Overpeck, 2000), including cold episodes (Johnson et al., 2018). Low temperatures can result in significant changes in coral physiology, bleaching, and mortality (Saxby, Dennison \& Hoegh-Guldberg, 2003; Kemp et al., 2011; Roth, Goericke \& Deheyn, 2012). Corals' response to cold stress, as is the case for heat stress, appears to vary regionally likely as a consequence of local adaptation, but also as an intricate combined function of the magnitude and duration of stress. In 1977, a cold-air front reduced 
61

water temperatures in Florida Bay to below $16^{\circ} \mathrm{C}$ for 8 consecutive days causing mortality of up to $91 \%$ of corals at some reef sites (Roberts et al., 1982). Another prolonged cold-water period with water temperatures below $11^{\circ} \mathrm{C}$ in 2010 resulted in $26 \%$ mean coral mortality in the Upper Florida Keys (Lirman et al., 2011; Kemp et al., 2016). Three consecutive months of below average winter minima $\left(\right.$ ca. $19^{\circ} \mathrm{C}$ ) caused approximately $60 \%$ of corals to bleach in Loreto in the Sea of Cortez in 2006 (LaJeunesse, Reyes-Bonilla \& Warner, 2007). A similar event in 2008 with temperatures below $17^{\circ} \mathrm{C}$ caused bleaching of up to $90 \%$ of Pocilloporid corals in the same region (LaJeunesse et al., 2010). In regions where corals are at risk from both hot and cold bleaching, such as the southern Great Barrier Reef (Hoegh-Guldberg \& Fine, 2004; Hoegh-Guldberg et al., 2005), there exists the possibility that reefs could experience two bleaching events within the same year, dramatically reducing vital recovery windows between thermal stressors. Furthermore, studies show that if cold stress occurs in combination with other global environmental changes, such as ocean acidification, the risk of coral mortality increases compared to low temperature stress in isolation (Kavousi, Parkinson \& Nakamura, 2016).

The Gulf of Aqaba (GoA) and northern Red Sea is a region highlighted for its lack of bleaching both during recent anomalously warm years in the field and during ex situ experiments (Bellworthy \& Fine, 2017; Krueger et al., 2017; Osman et al., 2018). This coral population is postulated to be adapted to warmer than present day seawater temperatures due to a warm water selection barrier at the entrance to the Red Sea, the Bab El Mendeb in the south (Fine, Gildor \& Genin, 2013). Experiments using GoA coral species have shown increased net oxygen production (proxy for algal symbiont productivity) at above ambient summer temperatures (Krueger et al., 2017). However, the response of these corals to cold stress events has not been 
84 tested. The reefs of the GoA are some of the northernmost in the world; limited research has

85

86

87

88

89

90

91

92

93

94 suggested that high latitude corals may have greater tolerance to cold stress than their tropical conspecifics (Tuckett \& Wernberg, 2018). In the northernmost part of the GoA, a steep slope from the forereef to a depth of 40-100 m may prevent major cold-water events on the shallow reef since denser cooler water will sink to greater depth. Yet, under doldrums conditions in lagoons and reef-flats, extreme cold conditions may develop. Furthermore, climate models for this region suggest that the Red Sea will soon enter a cooling phase (Krokos et al., 2019).

Since bleaching severity following cold water stress has previously been shown to be species specific (Coles \& Fadlallah, 1991; Zapata, Jaramillo-González \& Navas-Camacho, 2011; Kemp et al., 2016; Pontasch et al., 2017; Tuckett \& Wernberg, 2018), the responses of two species were compared in this study. Acroporid corals are the most abundant scleractinian genera in Eilat with Stylophora sp. the second most abundant (Shaked \& Genin, 2018). Acropora eurystoma is endemic to the Red Sea. Stylophora pistillata is particularly well studied at this site. Importantly, the response to heat stress of both species has been previously characterised (Bellworthy \& Fine, 2017). Both species are key reef building species, and their branching structure provides important habitat for many reef fish and invertebrates. The study was designed to answer two questions: 1 . How do two species from the GoA respond to below winter minimum water temperatures? 2. Does a recent cold winter experience make these corals more vulnerable to an acute warm period during summer?

\section{Materials \& Methods}

\section{Experimental design}


106 Corals were collected from the coral nursery (8 - 12 meters depth) adjacent to the Interuniversity

107 Institute (IUI) for Marine Sciences in Eilat, Israel (Gulf of Aqaba, Red Sea, 29³0'N, 34 $55^{\prime} \mathrm{E}$ ).

108 Sampling was conducted under permit no. 2018/41868 from the Israel Nature Parks Authority.

109 Average surface seawater temperature in the month prior to coral collection (February 2018) was

$11021.70 \pm 0.09^{\circ} \mathrm{C}$ (Eilat, 2020). The minimum monthly mean temperature between $2011-2018$ for

111 the collection site was $21.41 \pm 0.36^{\circ} \mathrm{C}$ (mean \pm standard deviation, data available:

112 http://www.meteo-tech.co.il/eilat-yam/eilat daily en.asp). Sea surface temperatures at the

113 collection site do not often fall below $21^{\circ} \mathrm{C}$ (Genin, Lazar \& Brenner, 1995; Eilat, 2020); the

114 minimum single point temperature since records began in 2007 (10 minute sampling interval) is

$11520.4^{\circ} \mathrm{C}$. The month with the coldest average temperature was February $2008\left(20.64 \pm 0.12^{\circ} \mathrm{C}\right.$;

116 mean \pm standard deviation).

117 Two species, Acropora eurystoma Klunzinger 1879 and Stylophora pistillata Esper 1797, were

118 collected. At this collection depth, S, pistillata likely hosted Symbiodiniaceae symbionts from

119 the genus Symbiodinium, formally clade A (Byler et al., 2013) and A. eurystoma with

120 Cladocopium sp., formly clade C (Karako-Lampert et al., 2004; LaJeunesse et al., 2018). Six

121 genotypes of each species with healthy appearance (i.e., no signs of bleaching, algal growth, or

122 predation) were selected. From each colony ( $n=6$ colonies $/$ species $) 10$ fragments of ca. $3 \mathrm{~cm}$

123 length were sampled resulting in a total of 60 fragments per species. Coral fragments were

124 brought to the Red Sea Simulator experimental system (Bellworthy \& Fine, 2018) and placed in

125 flow through aquaria with water sourced from the collection site. Twenty-four hours after

126 collection, corals were glued to bases to hold fragments upright and to facilitate handling.

127 Fragments were assigned to adjacent experimental aquaria ( $n=9$ aquariums). One fragment from 128 each genotype was placed randomly in each of the nine aquaria. This resulted in a total of 12 
129 fragments in each $40 \mathrm{~L}$ aquarium (6 fragments from each of two species). Fragments remained in

130 ambient seawater for two weeks acclimation to tank conditions, prior to the onset of cooling.

131 During this 'acclimation' period the corals were exposed to $290 \mu \mathrm{mol} \mathrm{m}^{-2} \mathrm{~s}^{-1}$ photosynthetically

132 active radiation (PAR) at midday which approximates the midday PAR the collection site in

133 winter (Dishon et al., 2012). Aquarium water temperatures for all phases of the experiment are

134 shown in Table 1.

135 In order to assess how these two species from the GoA respond physiologically to cold water

136 below ambient winter temperatures, a cold stress experiment was initiated in late-March. Corals

137 were exposed to three discrete treatment temperatures in a 'winter' phase (Table 1): ambient

138 control (T0), $1^{\circ} \mathrm{C}$ below winter minima (T-1), and $3{ }^{\circ} \mathrm{C}$ below winter minima (T-3). All

139 experimentation was conducted using the Red Sea Simulator (Bellworthy \& Fine, 2018) where

140 temperature was independently controlled in each aquarium. User defined settings and

141 environmental data were viewed and logged through custom software (Crystal OPC,

142 CrystalVision, Samar, Israel). Each treatment was replicated in three (triplicate) aquaria.

143 Ambient control aquaria (T0) were supplied with filtered seawater $(500 \mu \mathrm{m})$, direct from the

144 collection site, without temperature manipulation $\left(22.42 \pm 0.19^{\circ} \mathrm{C}\right)$. In T-1 and T-3 aquaria,

145 water temperature was decreased at 0.3 and $0.6^{\circ} \mathrm{C} /$ day, respectively, for 7 days. The cooling

146 rate is substantially more moderate than cold stress events reported in the field (Walker et al.,

147 1982; Lirman et al., 2011) and compared to previous empirical tests (Roth, Goericke \&

148 Deheyn, 2012; Pontasch et al., 2017) which reduce water temperature by up to $7^{\circ} \mathrm{C}$ in 11 hours.

149 It is therefore assumed that the cooling rate itself did not cause meaningful stress.

150 Following cooling, experimental temperatures of $20.53 \pm 0.46^{\circ} \mathrm{C}$ and $18.61 \pm 0.77^{\circ} \mathrm{C}$ (ca.

$151 \quad 1.1^{\circ} \mathrm{C}(\mathrm{T}-1)$ and $3.2^{\circ} \mathrm{C}(\mathrm{T}-3)$ below average winter temperature in 2018 , respectively) were 
152 maintained for 16 days. Cooling rate and experimental duration was chosen to be directly

153 comparable (but opposite) to a previous heat stress experiment at this site (Bellworthy \& Fine,

154 2017) but also relevant to the duration of cold-water events that have caused bleaching in the

155 field e.g. Florida Keys, January 2010 (Lirman et al., 2011). Desired temperature was set at an

156 offset from incoming seawater in order to maintain diel variability in aquaria.

157 After 16-days cold stress, seawater temperature was returned to ambient for all remaining

158 corals at the same rate as cooling occurred. Corals from all treatments were then maintained in

159 'common garden' aquaria with ambient seawater conditions for two months $\left(13^{\text {th }}\right.$ April $-11^{\text {th }}$

160 June 2018). Average seawater temperature during this period was $24.74 \pm 1.28{ }^{\circ} \mathrm{C}$ and

161 increased from ca. 22.8 to $25.7^{\circ} \mathrm{C}$ with natural seasonal warming.

162 The second experimental phase (mid-June) sought to investigate whether corals' cold winter

163 experience had any impact on response to a subsequent abrupt and acute warming event. In this

164 'summer' phase, remaining fragments $(\mathrm{N}$ total $=36$; one fragment per genotype $(n=6$

165 genotypes), per species $(n=2)$, per winter stress treatment $(n=3))$ were exposed, in triplicate

166 aquaria, to above local maximum monthly mean temperature. The summer phase consisted of a

167 single common above ambient temperature for all corals irrespective of their winter treatment

168 (Table 1). This period lasted for 7 days incorporating four days thermal ramping at $1^{\circ} \mathrm{C}$ day ${ }^{-1}$

169 followed by three days thermal hold.

170

171

\section{Sampling and physiological analyses}

172 One coral fragment from each genotype and each species was sampled from each treatment at

173 the end of each experimental period (winter and summer). A range of physiological parameters 
174 was assessed on each fragment as previously described (Bellworthy and Fine 2017). Briefly, 175 corals were dark acclimated for 20 minutes before a rapid light curve was performed on every

176 fragment (14 saturation pulses under increasing actinic light from $0-700 \mu \mathrm{mol} \mathrm{m}^{-2} \mathrm{~s}^{-1}$,

177 Imaging PAM, Walz GmbH, Germany). Maximum quantum yield $\left(\mathrm{F}_{\mathrm{V}} / \mathrm{F}_{\mathrm{M}}\right)$, is theoretically

178 independent from chlorophyll concentration and because samples are dark acclimated, is also

179 independent from ETR (Ralph \& Gademann, 2005). The equation of Hill et al. (2004) was used

180 in conjunction with the regression wizard tool of SigmaPlot v12 (SigmaStat, LaJolla, CA,

181 USA) to derive the parameters maximal relative electron transport rate ( $\left.r \mathrm{ETR}_{\mathrm{MAX}}\right)$, saturating

182 irradiance $\left(\mathrm{I}_{\mathrm{k}}\right)$, and initial slope of $r$ ETR under light limited conditions $(\alpha$; also known as

183 photosynthetic efficiency).

184 Subsequently, fragments were incubated in sealed, temperature-controlled chambers to

185 determine respiration (oxygen consumption) and net photosynthesis (oxygen production) rates

186 respectively. Respiration was measured in the dark $\left(<2 \mu \mathrm{mol} \mathrm{m}{ }^{-2} \mathrm{~s}^{-1}\right)$ and photosynthesis at 180

$187 \mu \mathrm{mol} \mathrm{m} \mathrm{m}^{-2} \mathrm{~s}^{-1}$. Chambers were placed on magnetic stirrers and fitted with a fibre optic oxygen sensor (PreSens) connected to an OXY-4 mini transmitter (PreSens) to follow change in oxygen concentration with incubation time. After incubations, fragments were individually wrapped in aluminium foil and flash frozen before storage at $-80^{\circ} \mathrm{C}$. Coral fragments were subsequently processed for protein concentration (Bradford 1976), chlorophyll $a$ concentration

192 (Jeffrey and Humphrey 1975), symbiont cell counts (FACS Attune NxT; cell identification by 193 fluorescence and size), and surface area utilising the wax dip method (Stimson and Kinzie 194 1991). 
196

197

198

199

200

201

202

203

204

205

206

207

208

209

210

211

212

213

214

215

216

217

218

\section{Statistical analyses}

Raw data were first visualized in order to assess distribution and inspect potential outliers. The parametric assumption of normal distribution was tested for each treatment group within the winter and summer periods separately using the Shapiro-Wilk normality test (shapiro.test, $\mathrm{R}$ package: \{stats\} (RCoreTeam, 2020)). The assumption of homogenous variances of data between each treatment was tested for each winter and summer period using Levene's Test (leveneTest, R package: \{car\} (Fox \& Weisberg, 2019)). No extreme violations were present in the raw data.

Linear mixed effects models (lmer, R package: $\{$ lme4\} (Bates et al., 2015)) were performed for each dependent variable in order to assess differences between treatment groups for each experimental period (i.e., winter and summer), with the fixed factor 'treatment' and the random factor 'genotype'. $P$-values and F-statistics were obtained using the command 'anova'. The contributions of the fixed and random factors to the model fit were assessed using the r.squaredGLMM function (R package: $\left\{\right.$ MuMIn\} (Bartoń, 2020)). The marginal $\mathrm{R}^{2}$ value indicates the proportion of variance explained by fixed factors alone, whereas the conditional $\mathrm{R}^{2}$ value indicates the proportion of variance explained by both fixed and random factors combined, thereby, in the current case, enabling identification of genotype effects. Model assumptions of normally distributed residuals and equal variance of residuals were tested. When assumptions were met and the model result was significant, post hoc tests were done to elucidate which treatment groups were significantly different (emmeans and $p w p m$, R package: \{emmeans $\},$ adj = "tukey" (Lenth, 2020)). Where model assumptions were violated, permutations were performed (permanova.lmer, R package: \{predictmeans\}). All statistical tests and graphics (R package: \{ggplot2\} (Wickham, 2016)) were produced in RStudio version 
2193.6 (https://www.r-project.org/ (RCoreTeam, 2020)). All raw data and R code for this

220 publication are available at

221 https://github.com/JessicaBellworthy/Bellworthy_Corals_Eilat_ColdStress

$223 \quad$ Results

During the 16-day winter period, all three treatments maintained similar diel variability in temperature. Approximately $2^{\circ} \mathrm{C}$ separated mean treatment values (Table 1). As incoming natural reef seawater temperature warmed through the cold stress phase, $\mathrm{T}-1$ represents an extended cold winter, and T-3 represents a sustained below ambient cold stress. During the summer phase, corals from all winter treatments experienced an above summer ambient temperature of $29.93 \pm 0.93^{\circ} \mathrm{C}$. During this period the ambient reef seawater temperature was $26.90 \pm 0.55^{\circ} \mathrm{C}$ (Eilat, 2020) and therefore the experimental temperature was ca. $3^{\circ} \mathrm{C}$ above ambient.

In both Stylophora pistillata and Acropora eurystoma, cold exposure significantly changed most of the examined physiological parameters compared to corals maintained in ambient seawater. Net photosynthesis in particular was almost non-existent in corals maintained at $\sim 18^{\circ} \mathrm{C}$ (A. eurystoma: $0.003 \pm 0.003 \mu \mathrm{mol} \mathrm{hr} \mathrm{cm}^{-1}$; S. pistillata: $0.016 \pm 0.020 \mu \mathrm{mol} \mathrm{hr}^{-1} \mathrm{~cm}^{-2}$,

Fig. 1). In three and two out of the six genotypes tested, there was no net oxygen production at 
240 this temperature for A. eurystoma and $S$. pistillata respectively (see data points below zero in

241 Fig. 1c and 1f). All photosynthetic parameters derived from light curves were significantly

242 different at $\sim 18^{\circ} \mathrm{C}$ compared to ambient winter temperature $\left(\sim 22^{\circ} \mathrm{C}\right)$. For example, in $A$.

243 eurystoma, maximal quantum yield $\left(\mathrm{F}_{\mathrm{V}} / \mathrm{F}_{\mathrm{M}}\right)$ was significantly reduced from a mean value of

$244 \quad 0.458 \pm 0.022$ at ambient to $0.359 \pm 0.030$ at $\sim 18^{\circ} \mathrm{C}$ (post hoc difference: $p=0.004$, Fig. 2 ). In

245 addition, cold stress had a significant impact on chlorophyll concentration in both species e.g.,

246 in S. pistillata reducing the ambient concentration of $39.28 \pm 6.19 \mu \mathrm{g} \mathrm{cm}^{-2}$ to $19.91 \pm 3.44 \mu \mathrm{g}$

$247 \mathrm{~cm}^{-2}$ in the coldest treatment $\left(\mathrm{T}-3, \sim 18^{\circ} \mathrm{C}\right.$, Fig. 1b). Protein concentration and respiration rate

248 were not significantly different between treatments for either species (Fig. 3). For A. eurystoma

249 symbiont cell density was also not significantly impacted by cold stress but for $S$. pistillata

250 symbiont cell density was significantly reduced at both below ambient temperatures relative to

251 ambient winter temperatures (Fig. 1, Table 2).

252 Statistical analyses suggest that coral genotype contributed near zero variation to the data for

253 six out of the nine parameters tested following cold stress in S. pistillata and five out of nine

254 parameters in A. eurystoma, i.e., marginal and conditional $\mathrm{R}^{2}$ values were equal (see methods

255 for explanation, Table 2). For A. eurystoma in the winter phase, variables with the greatest $\mathrm{R}^{2}$

256 values were $r \mathrm{ETR}_{\max }\left(\right.$ conditional $\left.\mathrm{R}^{2}=0.846\right)$ and $\mathrm{I}_{\mathrm{k}}$ (conditional $\left.\mathrm{R}^{2}=0.828\right)$. Similarly, for $S$.

257 pistillata winter variables with the greatest $\mathrm{R}^{2}$ values were $\mathrm{I}_{\mathrm{k}}\left(\right.$ conditional $\mathrm{R}^{2}=0.918$ ) and net

258 photosynthesis rate (conditional $\left.\mathrm{R}^{2}=0.832\right)$, closely followed by $r \mathrm{ETR}_{\max }$ (conditional $\mathrm{R}^{2}=$ $2590.830)$.

260

261

Impacts of cold stress on response an acute warm period 
262 Compared to the winter phase of the experiment, the summer phase resulted in fewer

263 significant differences between treatments. In other words, in most cases, corals' summer

264 response was independent of the winter temperature they experienced. The physiological

265 response during the warm period following cold exposure was different in the two species. For

266 A eurystoma at $30^{\circ} \mathrm{C}$, only $\mathrm{rETR}_{\max }$ and symbiont cell density were significantly lower in corals

267 that were exposed to $18^{\circ} \mathrm{C}$ in the winter compared to those that remained in ambient conditions

268 (Fig. 1 and 2). For S. pistillata at $30^{\circ} \mathrm{C}, \mathrm{I}_{\mathrm{k}}$ was significantly higher in corals from the $20^{\circ} \mathrm{C}(\mathrm{T}-$

269 1) winter treatment and $\alpha$ values were significantly lower in the $20^{\circ} \mathrm{C}(\mathrm{T}-1)$ and $18^{\circ} \mathrm{C}(\mathrm{T}-3)$

270 corals compared to the T0 treatment (Fig. 2). Correspondingly, the variables with the largest

271 conditional $\mathrm{R}^{2}$ were $r \operatorname{ETR}_{\max }(0.676)$ and photosynthetic $\alpha(0.800)$ for $A$. eurystoma and $S$.

272 pistillata respectively. All other parameters were not significantly different between treatments

273 (T0, T-1, T-3) during the summer phase.

\section{Discussion}

Stylophora pistillata and Acropora eurystoma were exposed to below ambient seawater temperatures in winter (March), followed by an acute warm period the following summer (June). These corals displayed physiological signs akin to a bleaching response below typical winter temperatures. Photophysiology, chlorophyll concentration, and net photosynthesis (oxygen production) declined (Fig. 1 and 2). Despite this, all corals survived the 16-day cold stress and later showed few physiological differences at $3^{\circ} \mathrm{C}$ above ambient compared to corals that did not experience a prior cold stress. These data indicate that experience of cold winter stress does not significantly reduce the known resistance of this population to above ambient 
284

285

286

287

288

289

290

291

292

293

294

295

296

297

298

299

300

301

302

303

304

305

306

summer temperatures. However, this study also shows for the first time that this population may be living critically close to its lower bleaching threshold which appears to represent a sublethal stress, at least in the short term, since host biomass (as measured by protein concentration) was maintained.

Following cold stress, most significant changes were observed within symbiont (cell density and chlorophyll concentration) and photophysiology parameters rather than coral host physiology (protein concentration and respiration; Table 2). This suggests that, for this population, the algal symbionts or at least chlorophyll fluorescence has a greater sensitivity to cooler temperatures than the coral host metabolism. Further work at this site could determine if symbiont identity influences the magnitude of cold-water bleaching as has been demonstrated by others (LaJeunesse et al., 2010). Declines in $\mathrm{F}_{\mathrm{V}} / \mathrm{F}_{\mathrm{M}}$ are commonly reported in symbiotic corals following cold stress (Saxby, Dennison \& Hoegh-Guldberg, 2003; Kemp et al., 2011; Pontasch et al., 2017), less so changes in host physiology as in the current study and therefore suggests that the coral animal may tolerate longer periods of cold stress before mortality (but see Kemp et al. (2011) who report significantly reduced respiration rate of three species from Florida under an extreme cold stress of $12^{\circ} \mathrm{C}$ ). Reductions in $\mathrm{F}_{\mathrm{V}} / \mathrm{F}_{\mathrm{M}}$ typically reflect dissipation of excess energy within the light harvesting antennae or photodamage to photosystem II. Changes in $\mathrm{F}_{\mathrm{V}} / \mathrm{F}_{\mathrm{M}}$ can be detected soon after the onset of stress, e.g. after three hours at 20, 16, and $12^{\circ} \mathrm{C}$, Montipora digitata reduced $\mathrm{F}_{\mathrm{V}} / \mathrm{F}_{\mathrm{M}}$ by $0.06,0.15$, and 0.22 respectively (Saxby, Dennison \& Hoegh-Guldberg, 2003). Stylophora sp. from Lord Howe Island showed a significant $79.8 \%$ decline in $\mathrm{F}_{\mathrm{V}} / \mathrm{F}_{\mathrm{M}}$ after 5 days' exposure to $15^{\circ} \mathrm{C}$ (Pontasch et al., 2017). Declining $\mathrm{F}_{\mathrm{V}} / \mathrm{F}_{\mathrm{M}}$ was also noted following a 5 hour acute cold stress in GoA species (supplementary information). Monitoring chlorophyll fluorescence therefore provides a fast, 
307

308

309

310

311

312

313

314

315

316

317

318

319

320

321

322

323

324

325

326

327

328

329

non-destructive, early indication of cold-water stress similar to how it has previously been used to indicate other environmental stressors (Cooper, Gilmour \& Fabricius, 2009).

A temperature response curve created using published empirical data (Fine, Gildor \& Genin, 2013; Bellworthy \& Fine, 2017; Krueger et al., 2017) from corals collected at this site shows how $\mathrm{F}_{\mathrm{V}} / \mathrm{F}_{\mathrm{M}}$ responds to temperature with ca. 2 weeks acclimation (Fig. 4). Highest $\mathrm{F}_{\mathrm{V}} / \mathrm{F}_{\mathrm{M}}$ occurs between 27 and $28.5^{\circ} \mathrm{C}$ (polynomial trend line, order 2) slightly above the maximum monthly mean for Eilat (Bellworthy \& Fine, 2017), adding support to the idea that corals at this site live below their thermal optimum and are adapted to higher temperatures (Fine, Gildor \& Genin, 2013; Krueger et al., 2017). In addition, Fig. 4 indicates that the lowest quantum yield occurs at the lowest experimental temperatures.

This study reports significant changes in other aspects of photochemistry not reported by previous studies (Table 2, Fig. 2). Reductions in maximal electron transport rate $\left(r \mathrm{ETR}_{\max }\right)$, saturation irradiance $\left(I_{K}\right)$, and photosynthetic efficiency $(\alpha)$ were noted for both species indicating inhibition of the photosynthetic apparatus under cold stress. Reductions in these parameters are often taken to infer high light stress and/ or high temperature stress (Warner, Fitt \& Schmidt, 1996; Bischof, Hanelt \& Wiencke, 2000; Fitt, Brown \& Warner, 2001; Beer et al., 2006) or acclimation to low irradiance (Anthony \& Hoegh-Guldberg, 2003; Cooper \& Ulstrup, 2009; Ross et al., 2018). As corals in this study were acclimated to outdoor aquaria (with similar PAR level to their collection site) before the onset of cold stress, this is unlikely the cause here. Therefore, whilst the mechanism of damage to the photosynthetic apparatus under cold stress is potentially symbiont type specific (Pontasch et al., 2017) and different than under high light or heat stress, the results suggest that the physiological outcome is similar i.e. reduction in symbiont density and photosynthetic capacity. Cellular mechanisms common to 
warm and cold-water bleaching responses may include damage to photosystem II reaction

331 centres (Wicks et al., 2010), changes in membrane fluidity (Tchnernov et al., 2004; Kemp et al., 2011), or RUBISCO enzyme activity (Saxby et al., 2003). Further work to describe cellular level thermal responses is likely to enhance scientific understanding.

Protein concentration did not decrease after two weeks cold stress despite significant decreases in symbiont photochemical efficiency and net photosynthesis rates (Table 2, Fig. 3). A similar result was noted for Montipora digitata where $\mathrm{F}_{\mathrm{v}} / \mathrm{F}_{\mathrm{m}}$ decreased more than $50 \%$ from initial values after two weeks at $17.6^{\circ} \mathrm{C}$ and yet did not display any corresponding decrease in protein concentration (Kavousi et al. 2016). Maintenance of total protein concentration and absence of mortality despite reduced energy production may be possible since metabolism, and therefore energy demand, decreases at lower temperatures (Schulte, Healy \& Fangue, 2011; Schulte, 2015) as has been demonstrated in corals (e.g. Coles \& Jokiel, 1977; Haryanti \& Hidaka, 2015). Declining metabolism is not evident in this study. Alternatively, but not necessarily mutually exclusive, corals may have metabolised stored lipids (Rodrigues \& Grottoli, 2007) or increased heterotrophic feeding (though corals were not explicitly provided with food, small zooplankton may enter the experimental aquaria through the $500 \mu \mathrm{m}$ seawater filter). Plasticity in energy acquisition modes is known to be important in determining the outcome of thermal stress in corals (Hughes \& Grottoli, 2013), not only in terms of mortality but also sub lethal processes such as growth and reproduction. Finally, increased heterotrophy during bleaching as has been demonstrated under high temperature stress (Grottoli, Rodrigues \& Palardy, 2006), may sustain coral animal functioning particularly if the cold stress cooccurs with the winter spring plankton bloom. 
352 The two studied species displayed similar responses to each other when experiencing either 353 below or above ambient temperatures. This contrasts previous species-specific responses observed in the field. For example, at Malpelo Island in Colombia, the only species to bleach in the winter of 2008 was Porites lobata with $31.4 \%$ of colonies affected (Zapata, JaramilloGonzález \& Navas-Camacho, 2011). Even within the genus Acropora, some species are more cold-tolerant than others (Higuchi et al., 2015). Temperature tolerance of conspecifics appears to be site specific and a function of local thermal adaptation rather than taxonomy. In contrast to the aforementioned Colombian reefs, within the coldest regions of the Arabian Gulf Porites sp. dominates coral cover and has minimal bleaching whereas Acropora and Stylophora colonies have limited cover and suffer severe mortality following cold stress (Coles \& Fadlallah, 1991). Testing other species from the diverse Red Sea may yet identify species specific responses though shallow water species from this site show a surprisingly consistent response to heat stress. Additionally, though not explicitly tested, based on prior knowledge (Byler et al., 2013) it is likely that all corals in this study hosted algal symbionts of the same genus. Since cold stress primarily affected the symbionts in this study, potentially the same coral species with a different symbiont may have a contrasting cold-stress response as demonstrated elsewhere (LaJeunesse et al., 2010). Correspondingly, the cold stress response of deeper (mesophotic) corals which host different symbiont genera at this study site, remains to be explored (Byler et al., 2013; Scucchia et al., 2020). All open questions raised here will likely

371 be pertinent future research as both hot and cold thermal extremes increase in magnitude and 372 frequency.

373 Seasonal changes in coral physiology (Fitt et al., 2000) may sometimes be misinterpreted as stress symptoms, highlighting the importance of generating seasonal physiological baselines at 
375

376

377

378

379

380

381

382

383

384

385

386

387

388

389

390

391

392

393

394

395

396

397

different spatial scales (local, regional, and beyond). For example, in this study protein concentration, chlorophyll concentration, and net photosynthetic rate all appear reduced in the summer compared to wintertime for S. pistillata (Fig. 1 and 3). In A. eurystoma, net photosynthetic rate also appears depressed in the summer (Fig. 1). Nevertheless, there were few significant differences between treatment groups following the warm period indicating that exposure to winter cold stress does not impact corals' response to above ambient summer temperatures. These results add further conceptual support to the Red Sea Reef Refuge Hypothesis of Fine et al. (2013). The evolutionary mechanism behind this hypothesis suggests that coral recruits resistant to high water temperatures established the present-day Red Sea population. Thus, these corals had little evolutionary experience to build cold water tolerance. Whilst GoA corals are rightly celebrated for presently living relatively far below their upper bleaching threshold (Fine, Gildor \& Genin, 2013) and tolerate a relatively wide natural temperature range (ca. $21-27^{\circ} \mathrm{C}$ ), bleaching in this study has shown that their thermal plasticity is not boundless. In fact, GoA corals live relatively close to their lower bleaching temperature relative to other reefs (Table S1). Interestingly, Scleractinian species that show greatest mean summer mortality in the Florida reef tract have lowest mortality following a cold winter (Lirman et al., 2011). Here we suggest that the opposite trade off of high temperature tolerance with cold-water sensitivity may be present in GoA corals. We hypothesise that along the latitudinal and thermal gradient in the Red Sea, corals live closer to their upper thermal limits towards the south and the opposite latitudinal trend exists for cold temperature thresholds i.e., northernmost reefs are more likely to experience cold water bleaching.

The Red Sea is warming rapidly with the northern section warming faster than the global average. Some models predict increasing frequency and intensity of heat waves (Genevier et

Peer) reviewing PDF | (2020:11:55465:1:1:CHECK 13 Jan 2021) 
398 al., 2019) whilst others suggest the present warming trend will be counteracted due to natural 399 climate oscillations shifting the Red Sea into a cooling phase in the upcoming decades (Krokos 400 et al., 2019). Contradictions between available models add uncertainty to our ability to predict 401 whether cold stress events will become problematic in the GoA. If an extreme cold weather 402 scenario materializes, it will put the acclimation and longer-term adaptation potential of these 403 corals to the test. Whilst corals of the GoA presently live relatively far from their upper thermal 404 threshold (Fine, Gildor \& Genin, 2013; Bellworthy \& Fine, 2017; Krueger et al., 2017), they 405 are in fact precariously close to their cold-water bleaching temperature.

Acknowledgements: We are grateful to Dror Komet for assistance with collection of the corals and maintenance of the Red Sea Simulator System. Many thanks to colleagues and three reviewers who reviewed and improved the manuscript prior to submission. In addition, thanks go to Roi Holzman and Tal Perevolotsky for guidance in completing the statistical analyses along with Ronen Liberman who supported the construction of graphical elements. 


\section{References}

406

407

408

409

410

411

412

413

414

415

416

417

418

419

420

421

422

423

424

425

426

427

428

429

430

431

432

433

434

435

436

437

438

439

Anthony KRN, Hoegh-Guldberg O. 2003. Kinetics of photoacclimation in corals. Oecologia 134:23-31. DOI: 10.1007/s00442-002-1095-1.

Bartoń K. 2020. MuMIn: Multi-Model Inference. :R package version 1.43.17.-R package version 1.43 .

Bates D, Maechler M, Bolker B, Walker S. 2015. Fitting Linear Mixed-Effects Models Using lme4. Journal of Statistical Software 67:1-48. DOI: 10.18637/jss.v067.i01.

Beer S, Mtolera M, Lyimo T, Björk M. 2006. The photosynthetic performance of the tropical seagrass Halophila ovalis in the upper intertidal. Aquatic Botany 84:367-371. DOI: 10.1016/j.aquabot.2005.11.007.

Bellworthy J, Fine M. 2017. Beyond peak summer temperatures, branching corals in the Gulf of Aqaba are resilient to thermal stress but sensitive to high light. Coral Reefs 36. DOI: $10.1007 / \mathrm{s} 00338-017-1598-1$.

Bellworthy J, Fine M. 2018. The Red Sea Simulator: A high-precision climate change mesocosm with automated monitoring for the long-term study of coral reef organisms. Limnology and Oceanography: Methods 16. DOI: 10.1002/lom3.10250.

Bischof K, Hanelt D, Wiencke C. 2000. Effects of ultraviolet radiation on photosynthesis and related enzyme reactions of marine macroalgae. Planta 211:555-562. DOI: $10.1007 / \mathrm{s} 004250000313$.

Byler KA, Carmi-Veal M, Fine M, Goulet TL. 2013. Multiple symbiont acquisition strategies as an adaptive mechanism in the coral Stylophora pistillata. PLoS ONE 8:1-7. DOI: 10.1371/journal.pone.0059596.

Coles SL, Fadlallah YH. 1991. Reef coral survival and mortality at low temperatures in the Arabian Gulf: new species-specific lower temperature limits. Coral Reefs 9:231-237. DOI: 10.1007/BF00290427.

Coles SL, Jokiel PL. 1977. Effects of temperature on photosynthesis and respiration in hermatypic corals. Marine Biology 43:209-216. DOI: 10.1007/BF00402313.

Cooper TF, Gilmour JP, Fabricius KE. 2009. Bioindicators of changes in water quality on coral reefs: Review and recommendations for monitoring programmes. Coral Reefs 28:589-606. DOI: $10.1007 / \mathrm{s} 00338-009-0512-\mathrm{x}$.

Cooper TF, Ulstrup KE. 2009. Mesoscale variation in the photophysiology of the reef building coral Pocillopora damicornis along an environmental gradient. Estuarine, Coastal and Shelf Science 83:186-196. DOI: 10.1016/j.ecss.2009.03.015.

Dana JD. 1843. On the temperature limiting the distribution of coral reefs. American Journal of Science 45:130-231. 
440

441

442

443

444

445

446

447

448

449

450

451

452

453

454

455

456

457

458

459

460

461

462

463

464

465

466

467

468

469

470

471

472

473

474

475

Dishon G, Dubinsky Z, Fine M, Iluz D. 2012. Underwater light field patterns in subtropical coastal waters: A case study from the Gulf of Eilat (Aqaba). Israel Journal of Plant Sciences 60:265-275. DOI: 10.1560/ijps.60.1-2.265.

Israel National Monitoring Program of the Gulf of Eilat. 2020. Available at http://www.meteotech.co.il/eilat-yam/eilat_en.asp

Fine M, Gildor H, Genin A. 2013. A coral reef refuge in the Red Sea. Global Change Biology 19:3640-3647. DOI: $10.1111 / \mathrm{gcb} .12356$.

Fitt WK, Brown BE, Warner ME. 2001. Coral bleaching: Interpretation of thermal tolerance limits and thermal thresholds in tropical corals. Coral Reefs 20:51-65. DOI: $10.1007 / \mathrm{s} 003380100146$.

Fitt WK, McFarland FK, Warner ME, Chilcoat GC. 2000. Seasonal patterns of tissue biomass and densities of symbiotic dinoflagellates in reef corals and relation to coral bleaching. Limnology and Oceanography 45:677-685. DOI: 10.4319/lo.2000.45.3.0677.

Fox J, Weisberg S. 2019. An $\{R\}$ Companion to Applied Regression. Thousand Oaks, CA: Sage.

Genevier LGC, Jamil T, Raitsos DE, Krokos G, Hoteit I. 2019. Marine heatwaves reveal coral reef zones susceptible to bleaching in the Red Sea. Global Change Biology:doi: 10.1111/gcb.14652-doi: 10.1111/gcb.14652. DOI: 10.1111/gcb.14652.

Genin A, Lazar B, Brenner S. 1995. Vertical mixing and coral death in the red sea following the eruption of Mount Pinatubo. Nature 377:507-510. DOI: 10.1038/377507a0.

Grottoli AG, Rodrigues LJ, Palardy JE. 2006. Heterotrophic plasticity and resilience in bleached corals. Nature 440:1186-1189. DOI: 10.1038/nature04565.

Haryanti D, Hidaka M. 2015. Temperature dependence of respiration in larvae and adult colonies of the corals Acropora tenuis and Pocillopora damicornis. Journal of Marine Science and Engineering 3:509-519. DOI: 10.3390/jmse3030509.

Higuchi T, Agostini S, Casareto BE, Suzuki Y, Yuyama I. 2015. The northern limit of corals of the genus Acropora in temperate zones is determined by their resilience to cold bleaching. Scientific Reports 5:1-9. DOI: 10.1038/srep18467.

Hill R, Larkum AWD, Schreiber U, Kühl M, Ralph PJ, Gademann R. 2004. Spatial heterogeneity of photosynthesis and the effect of temperature-induced bleaching conditions in three species of corals. Marine Biology 144:633-640. DOI: 10.1007/s00227-003-1226-1.

Hoegh-Guldberg O, Fine M. 2004. Low temperatures cause coral bleaching. Coral Reefs 23:444. DOI: $10.1007 / \mathrm{s} 00338-004-0401-2$.

Hoegh-Guldberg O, Fine M, Skirving W, Johnstone R, Dove S, Strong A, Skirving W, Dove S, Hoegh-Guldberg O, Johnstone R, Fine M, Skirving W, Johnstone R, Dove S, Strong A. 2005. Coral bleaching following wintry weather. Limnology and Oceanography 50:265271. DOI: $10.4319 / 10.2005 .50 .1 .0265$. 
476

477

478

479

480

481

482

483

484

485

486

487

488

489

490

491

492

493

494

495

496

497

498

499

500

501

502

503

504

505

506

507

508

509

510

511

512

513

Hoegh-Guldberg O, Poloczanska ES. 2017. Editorial: The Effect of Climate Change across Ocean Regions. Frontiers in Marine Science 4:1-4. DOI: 10.3389/fmars.2017.00361.

Hughes AD, Grottoli AG. 2013. Heterotrophic compensation: a possible mechanism for resilience of coral reefs to global warming or a sign of prolonged stress? PLOS ONE 8:e81172-e81172. DOI: 10.1371/journal.pone.0081172.

Johnson NC, Xie SP, Kosaka Y, Li X. 2018. Increasing occurrence of cold and warm extremes during the recent global warming slowdown. Nature Communications 9: DOI: 10.1038/s41467-018-04040-y.

Karako-Lampert S, Katcoff DJ, Dubinsky Z, Stambler N. 2004. Do clades of symbiotic dinoflagellates in scleractinan corals of the Gulf of Eilat (Red Sea) differ from those of other coral reefs? Journal of Experimental Marine Biology and Ecology 311:301-314. DOI: 10.1016/j.jembe.2004.05.015.

Kavousi J, Parkinson JE, Nakamura T. 2016. Combined ocean acidification and low temperature stressors cause coral mortality. Coral Reefs 35:903-907. DOI: 10.1007/s00338-016-1459-3.

Kemp DW, Colella MA, Bartlett LA, Ruzicka RR, Porter JW, Fitt WK. 2016. Life after cold death: reef coral and coral reef responses to the 2010 cold water anomaly in the Florida Keys. Ecosphere 7: DOI: 10.1002/ecs2.1373.

Kemp DW, Oakley CA, Thornhill DJ, Newcomb LA, Schmidt GW, Fitt WK. 2011. Catastrophic mortality on inshore coral reefs of the Florida Keys due to severe low-temperature stress. Global Change Biology 17:3468-3477. DOI: 10.1111/j.1365-2486.2011.02487.x.

Kleypas JA, Mcmanusi JW, Menez LAB. 1999. Environmental limits to coral reef development: where do we draw the line? American Zoologist 39:146-159.

Krokos G, Papadopoulos VP, Sofianos SS, Ombao H, Dybczak P, Hoteit I. 2019. Natural climate oscillations may counteract Red Sea warming over the coming decades. Geophysical Research Letters 46:3454-3461. DOI: 10.1029/2018GL081397.

Krueger T, Horwitz N, Bodin J, Giovani M-E, Escrig S, Meibom A, Fine M. 2017. Common reef-building coral in the Northern Red Sea resistant to elevated temperature and acidification. Royal Society Open Science 4: DOI: 10.1098/rsos.170038.

LaJeunesse TC, Reyes-Bonilla H, Warner ME. 2007. Spring "bleaching" among Pocillopora in the Sea of Cortez, Eastern Pacific. Coral Reefs 26:265-270. DOI: 10.1007/s00338-0060189-3.

LaJeunesse TC, Smith R, Walther M, Pinzón J, Pettay DT, McGinley M, Aschaffenburg M, Medina-Rosas P, Cupul-Magaña AL, Pérez AL, Reyes-Bonilla H, Warner ME. 2010. Hostsymbiont recombination versus natural selection in the response of coral-dinoflagellate symbioses to environmental disturbance. Proceedings of the Royal Society B: Biological Sciences 277:2925-2934. DOI: 10.1098/rspb.2010.0385.

LaJeunesse TC, Parkinson JE, Gabrielson PW, Jeong HJ, Reimer JD, Voolstra CR, Santos SR. (2018) Systematic revision of Symbiodiniaceae highlights the antiquity and diversity of 
coral endosymbionts. Current Biology 28:2570-2580. DOI: 10.1016/j.cub.2018.07.008

515

Lenth R. 2020. emmeans: Estimated Marginal Means, aka Least-Squares Means. :R package version 1.4.6.-R package version 1.4.6.

Lirman D, Schopmeyer S, Manzello D, Gramer LJ, Precht WF, Muller-Karger F, Banks K, Barnes B, Bartels E, Bourque A, Byrne J, Donahue S, Duquesnel J, Fisher L, Gilliam D, Hendee J, Johnson M, Maxwell K, McDevitt E, Monty J, Rueda D, Ruzicka R, Thanner S. 2011. Severe 2010 cold-water event caused unprecedented mortality to corals of the Florida Reef Tract and reversed previous survivorship patterns. PLOS ONE 6: DOI: 10.1371/journal.pone.0023047.

Mayor AG. 1914. The effects of temperature on tropical marine animals. Carnegie Institution of Washington Publications 183:1-24.

Nakabayashi A, Yamakita T, Nakamura T, Aizawa H, Kitano YF, Iguchi A, Yamano H, Nagai S, Agostini S, Teshima KM, Yasuda N. 2019. The potential role of temperate Japanese regions as refugia for the coral Acropora hyacinthus in the face of climate change. Scientific Reports 9:1-12. DOI: 10.1038/s41598-018-38333-5.

Osman EO, Smith DJ, Ziegler M, Kürten B, Conrad C, El-Haddad KM, Voolstra CR, Suggett DJ. 2018. Thermal refugia against coral bleaching throughout the northern Red Sea. Global Change Biology 24: DOI: 10.1111/gcb.13895.

Pontasch S, Fisher PL, Krueger T, Dove S, Hoegh-Guldberg O, Leggat W, Davy SK. 2017. Photoacclimatory and photoprotective responses to cold versus heat stress in high latitude reef corals. Journal of Phycology. DOI: 10.1111/jpy.12492.

Ralph PJ, Gademann R. 2005. Rapid light curves: A powerful tool to assess photosynthetic activity. Aquatic Botany 82:222-237. DOI: 10.1016/j.aquabot.2005.02.006.

RCoreTeam. 2020. R: A language and environment for statistical computing.

Roberts HH, Rouse L J J, Walker ND, Hudson JH. 1982. Cold-water stress in Florida Bay and northern Bahamas: a product of winter cold-air outbreaks. Journal of Sedimentary Research 52:145-155. DOI: 10.1306/212f7efa-2b24-11d7-8648000102c1865d.

Rodrigues LJ, Grottoli AG. 2007. Energy reserves and metabolism as indicators of coral recovery from bleaching. Limnology and Oceanography 52:1874-1882. DOI: 10.4319/1o.2007.52.5.1874.

Ross CL, Schoepf V, DeCarlo TM, McCulloch MT. 2018. Mechanisms and seasonal drivers of calcification in the temperate coral Turbinaria reniformis at its latitudinal limits.

Proceedings of the Royal Society B: Biological Sciences 285: DOI: 10.1098/rspb.2018.0215.

Roth MS, Goericke R, Deheyn DD. 2012. Cold induces acute stress but heat is ultimately more deleterious for the reef-building coral Acropora yongei. Scientific Reports 2: DOI: $10.1038 /$ srep00240. 
551

552

553

554

555

556

557

558

559

560

561

562

563

564

565

566

567

568

569

570

571

572

573

574

575

576

577

578

579

580

581

582

583

584

585

586

587

Saxby T, Dennison WC, Hoegh-Guldberg O. 2003. Photosynthetic responses of the coral Montipora digitata to cold temperature stress. Marine Ecology Progress Series 248:85-97.

Schulte PM. 2015. The effects of temperature on aerobic metabolism: Towards a mechanistic understanding of the responses of ectotherms to a changing environment. Journal of Experimental Biology 218:1856-1866. DOI: 10.1242/jeb.118851.

Schulte PM, Healy TM, Fangue NA. 2011. Thermal performance curves, phenotypic plasticity, and the time scales of temperature exposure. Integrative and Comparative Biology 51:691702.

Scucchia F, Nativ H, Neder M, Goodbody-Gringley, Mass T. 2020 Physiological characteristics of Stylophora pistillata larvae across a depth gradient. Frontiers in Marine Science 7: DOI: 10.3389/fmars.2020.00013

Shaked Y, Genin A. 2018. The Israel National Monitoring Program in the Northern Gulf of Aqaba. Scientific Report 2018. Eilat, Israel.

Tchernov D, Gorbunov MJ, de Vargas C, Yadav SN, Miligan AJ, Haggblom M, Falkowski PG. 2004. Membrane lipids of symbiotic algae are diagnostic of sensitivity to thermal bleaching in corals. Proceedings of the National Academy of Sciences USA 101:13531-5

Tuckett CA, Wernberg T. 2018. High latitude corals tolerate severe cold spell. Frontiers in Marine Science 5:1-6. DOI: 10.3389/fmars.2018.00014.

Urban FE, Cole JE, Overpeck JT. 2000. Influence of mean climate change on climate variability from a 155-year tropical Pacific coral record. Nature 407:989-993. DOI: $10.1038 / 35039597$.

Vaughan TW, Wells JW. 1943. Revision of the suborders families, and genera of the scleractinia. Special Paper of the Geological Society of America 44:1-343. DOI: 10.1130/SPE44-p1.

Walker ND, Roberts HH, Rouse LJ, Huh OK. 1982. Thermal history of reef-associated environments during a record cold-air outbreak event. Coral Reefs 1:83-87. DOI: 10.1007/BF00301689.

Warner ME, Fitt WK, Schmidt GW. 1996. The effects of elevated temperature on the photosynthetic efficiency of zooxanthellae in hospite from four different species of reef coral: A novel approach. Plant Cell and Environment 19:291-299. DOI: 10.1111/j.13653040.1996.tb00251.x.

Wickham H. 2016. Elegant graphics for data analysis. New York: Springer-Verlag.

Wicks LC, Hill R, Davy SK. 2010. The influence of irradiance on tolerance to high and low temperature stress exhibited by Symbiodinium in the coral Pocillopora damicornis, from the high-latitude reef of Lord Howe Island. Limnology and Oceanography 55: 2476-86

Zapata FA, Jaramillo-González J, Navas-Camacho R. 2011. Extensive bleaching of the coral Porites lobata at Malpelo Island, Colombia, during a cold water episode in 2009. Bulletin of

Peer) reviewing PDF | (2020:11:55465:1:1:CHECK 13 Jan 2021) 


\section{Table $\mathbf{1}$ (on next page)}

Automated temperature recordings in experimental aquaria ca. every 5 minutes throughout the experiment (every 10 minutes during ambient recovery phase).

Temperature change refers to the rate of temperature decrease from ambient in the cold stress 'winter' phase. Values are treatment averages of all recorded values (day and night) for each period from triplicate aquaria combined (mean \pm standard deviation). Acclimation refers to the days corals were in experimental aquaria before onset of cooling. Winter refers to the 16-day cold stress experimental period at minimal temperatures (i.e. $28^{\text {th }}$ March $-12^{\text {th }}$ April). Recovery: two months in 'common garden' aquaria at ambient seawater temperature.

Summer refers to acute heat shock (maximal temperature hold days) $11^{\text {th }}-13^{\text {th }}$ June. During the summer phase, fragments from all winter treatments were combined into three replicate heated aquaria with a common above ambient temperature. 


\begin{tabular}{|c|c|c|c|c|c|}
\hline \multirow[t]{2}{*}{ Treatment } & \multirow{2}{*}{$\begin{array}{l}\text { Temperature } \\
\text { change }\left({ }^{\circ} \mathrm{C} \mathrm{d}^{-1}\right)\end{array}$} & \multicolumn{4}{|c|}{ Temperature $\left({ }^{\circ} \mathrm{C}\right)$} \\
\hline & & Acclimation & Winter & Recovery & Summer \\
\hline T0 & -0.0 & $20.27 \pm 0.37$ & $22.42 \pm 0.19$ & $24.74 \pm 1.28$ & $29.93 \pm 0.93$ \\
\hline $\mathrm{T}-1$ & -0.3 & $20.70 \pm 0.65$ & $20.53 \pm 0.46$ & & \\
\hline $\mathrm{T}-3$ & -0.6 & $20.38 \pm 0.45$ & $18.61 \pm 0.77$ & & \\
\hline
\end{tabular}

1

2 


\section{Table 2 (on next page)}

Statistical analyses of differences in physiological parameters between treatments within each experimental period (winter cold stress and summer heat shock) for each species.

Results were obtained from linear mixed models where model residuals were normally distributed with equal variance between groups (fixed factor $=$ treatment, random factor $=$ genotype). Where data did not meet assumptions of parametric tests, permanova models were performed as indicated by ${ }^{\dagger}$. Bold $p$ values indicate statistical significance $(\alpha=0.05)$. ' $m$ ': Marginal $R^{2}$ value, the proportion of variance explained by fixed factors alone. ' $c$ ':

Conditional $\mathrm{R}^{2}$ value, the proportion of variance explained by both fixed and random factors combined. 


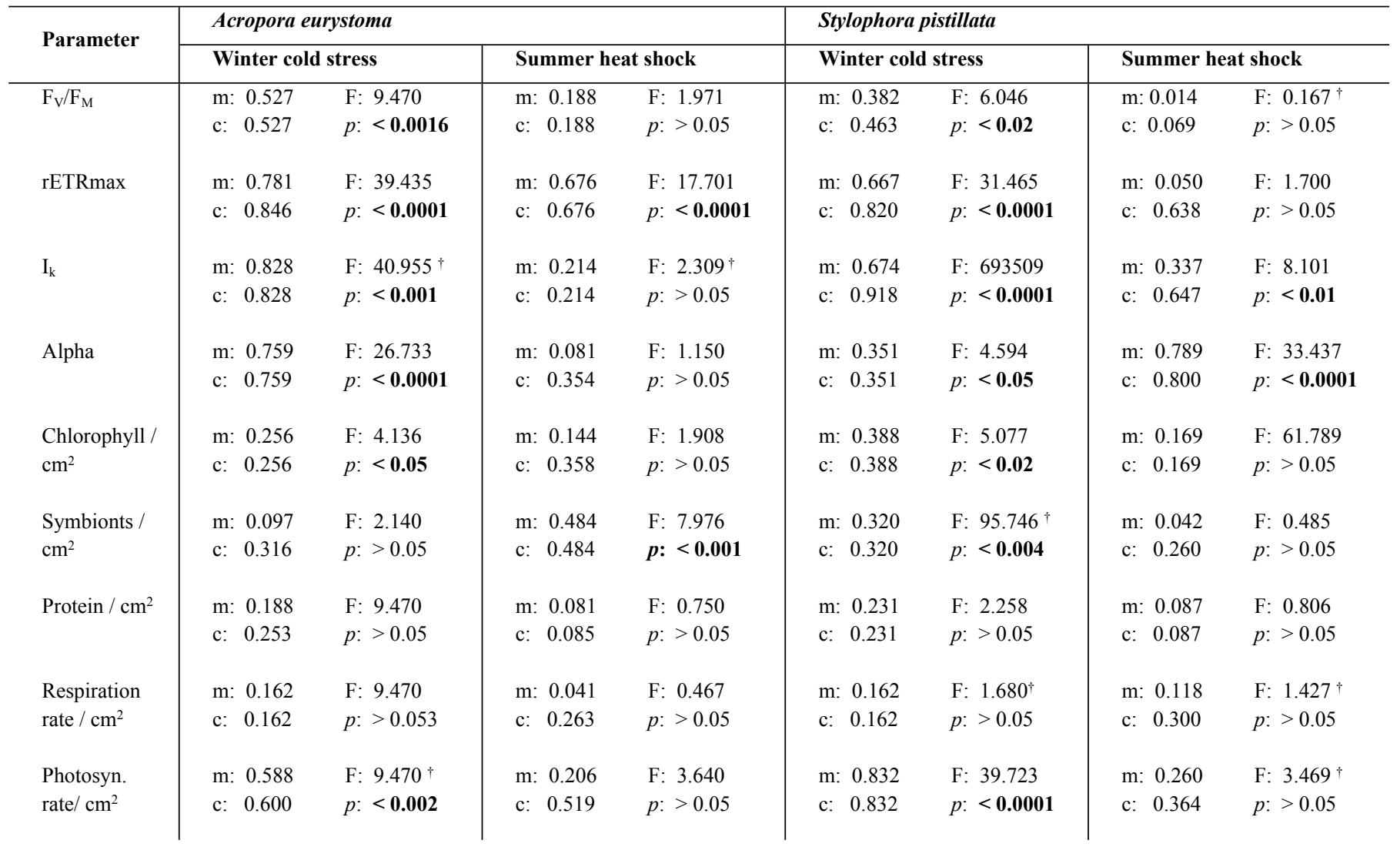

1

2

3

4

5

6 


\section{Figure 1}

Figure 1 Response of algal symbionts of Stylophora pistillata (A - C) and Acropora eurystoma $(D-F)$ exposed to below annual minima temperatures

yellow $=22.4^{\circ} \mathrm{C}$, blue $=20.5^{\circ} \mathrm{C}$, grey $=18.6^{\circ} \mathrm{C}$ ( $\mathrm{n}=5$ or $6 /$ species /treatment). Box fill colours reflect the different winter thermal experience of these corals. During 'summer' all corals were exposed to $3^{\circ} \mathrm{C}$ above maximum monthly mean. Plots are symbiont cell density $(A, D)$, chlorophyll concentration $(B, E)$, rate of net oxygen production $(C, F)$. Boxes display the median line, the first and third quartiles (box outline) and whiskers are 1.5 times the interquartile range. Shaped points refer to coral genotypes, consistent to all plots. Different lowercase letters denote significant treatment effects within each experimental phase (winter and summer, Linear Mixed Effect Model and Tukey post hoc test). 
STYLOPHORA
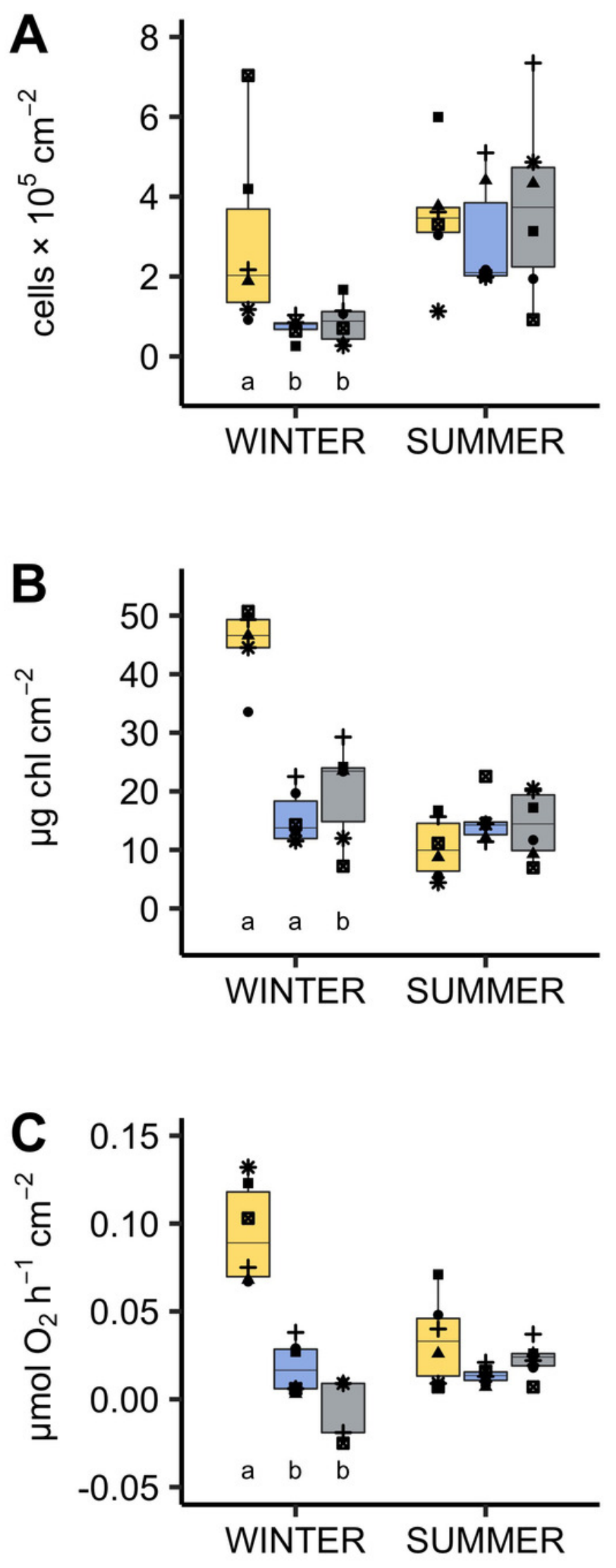

ACROPORA
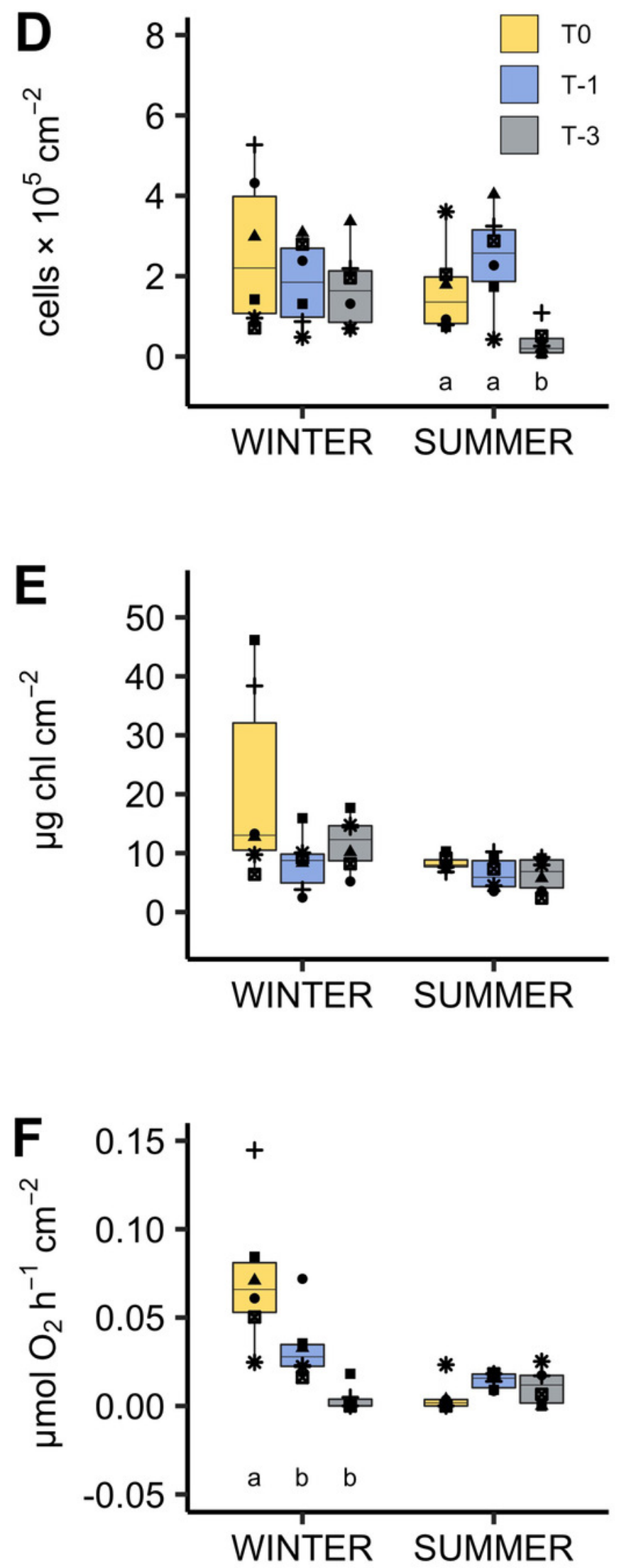


\section{Figure 2}

Figure 2 Photophysiology of algal symbionts of Stylophora pistillata (A - D) and Acropora eurystoma $(D-H)$ exposed to below annual minima temperatures

yellow $=22.4^{\circ} \mathrm{C}$, blue $=20.5^{\circ} \mathrm{C}$, grey $=18.6^{\circ} \mathrm{C}$ ( $\mathrm{n}=5$ or $6 /$ species /treatment). Box fill colours reflect the different winter thermal experience of these corals. During 'summer' all corals were exposed to $3^{\circ} \mathrm{C}$ above maximum monthly mean. $\mathrm{F}_{\mathrm{v}} / \mathrm{F}_{\mathrm{M}}$ : Maximum quantum yield

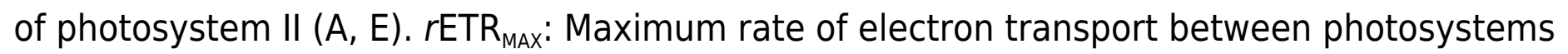
(B, F). $\alpha$ : photosynthetic efficiency (C, G). I : saturating irradiance for photosynthesis, $\mu \mathrm{mol}$ $\mathrm{m}^{-2} \mathrm{~s}^{-1}(\mathrm{D}, \mathrm{H})$. Boxes display the median line, the first and third quartiles (box outline) and whiskers are 1.5 times the interquartile range. Shaped points refer to coral genotypes, consistent to all plots. Different lowercase letters denote significant treatment effects within each experimental phase (winter and summer, Linear Mixed Effect Model and Tukey post hoc test). 
STYLOPHORA

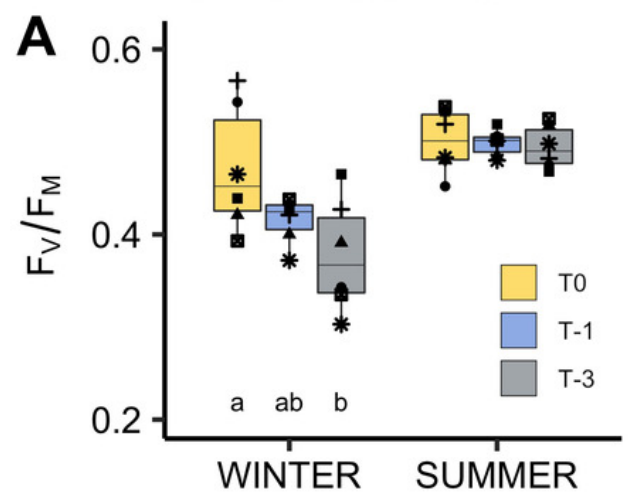

ACROPORA
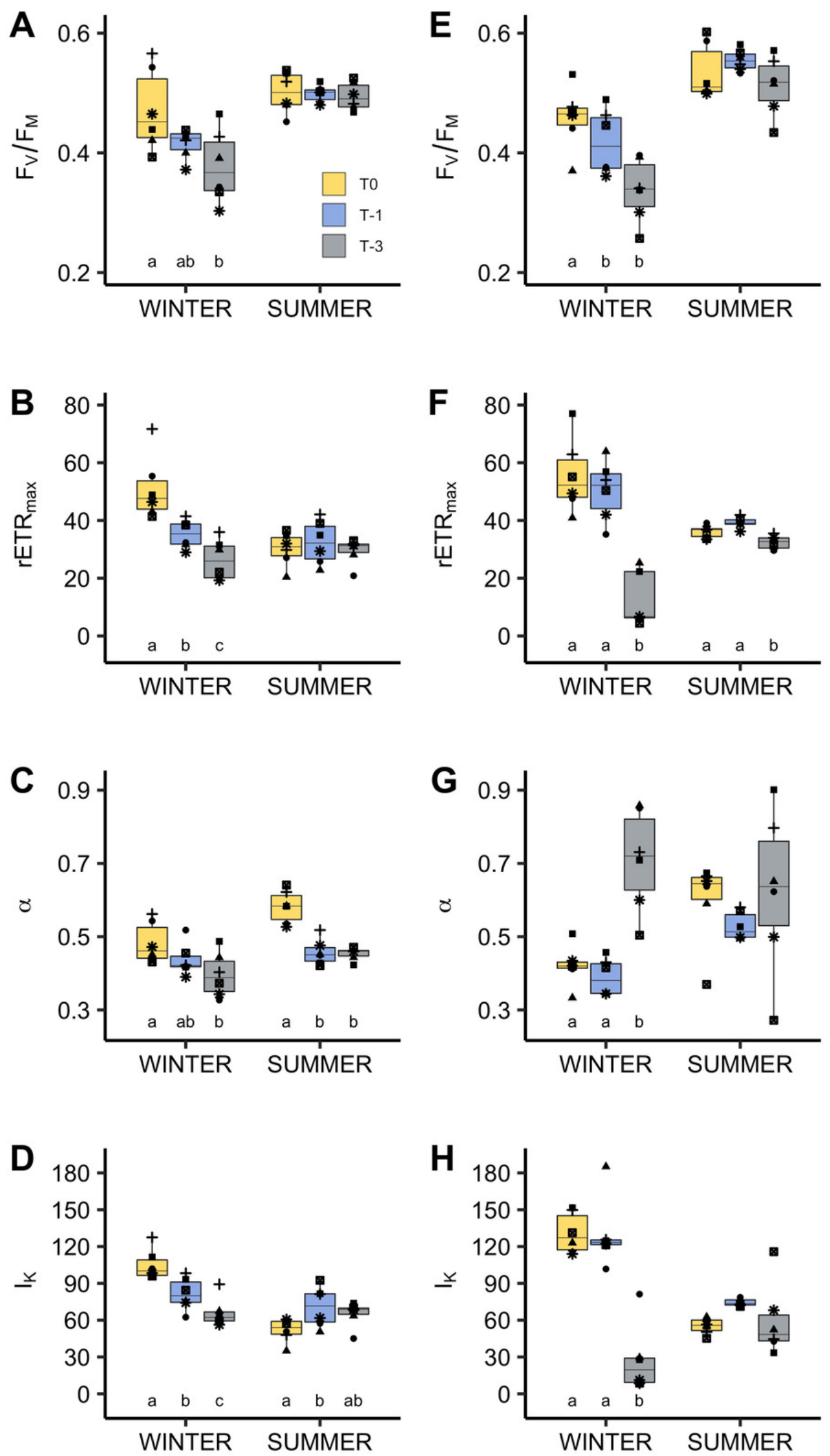


\section{Figure 3}

Figure 3 Response of Stylophora pistillata (A - B) and Acropora eurystoma (C - D) exposed to below annual minima temperatures

yellow $=22.4^{\circ} \mathrm{C}$, blue $=20.5^{\circ} \mathrm{C}$, grey $=18.6^{\circ} \mathrm{C}$ ( $\mathrm{n}=5$ or $6 /$ species /treatment). Box fill colours reflect the different winter thermal experience of these corals. During 'summer' all corals were exposed to $3^{\circ} \mathrm{C}$ above maximum monthly mean. Plots are holobiont protein concentration $(A, C)$ and rate of oxygen consumption in the dark i.e. respiration rate $(B, D)$. Boxes display the median line, the first and third quartiles (box outline) and whiskers are 1.5 times the interquartile range. Shaped points refer to coral genotypes, consistent to all plots. Different lowercase letters denote significant treatment effects within each experimental phase (winter and summer, Linear Mixed Effect Model and Tukey post hoc test). 
STYLOPHORA
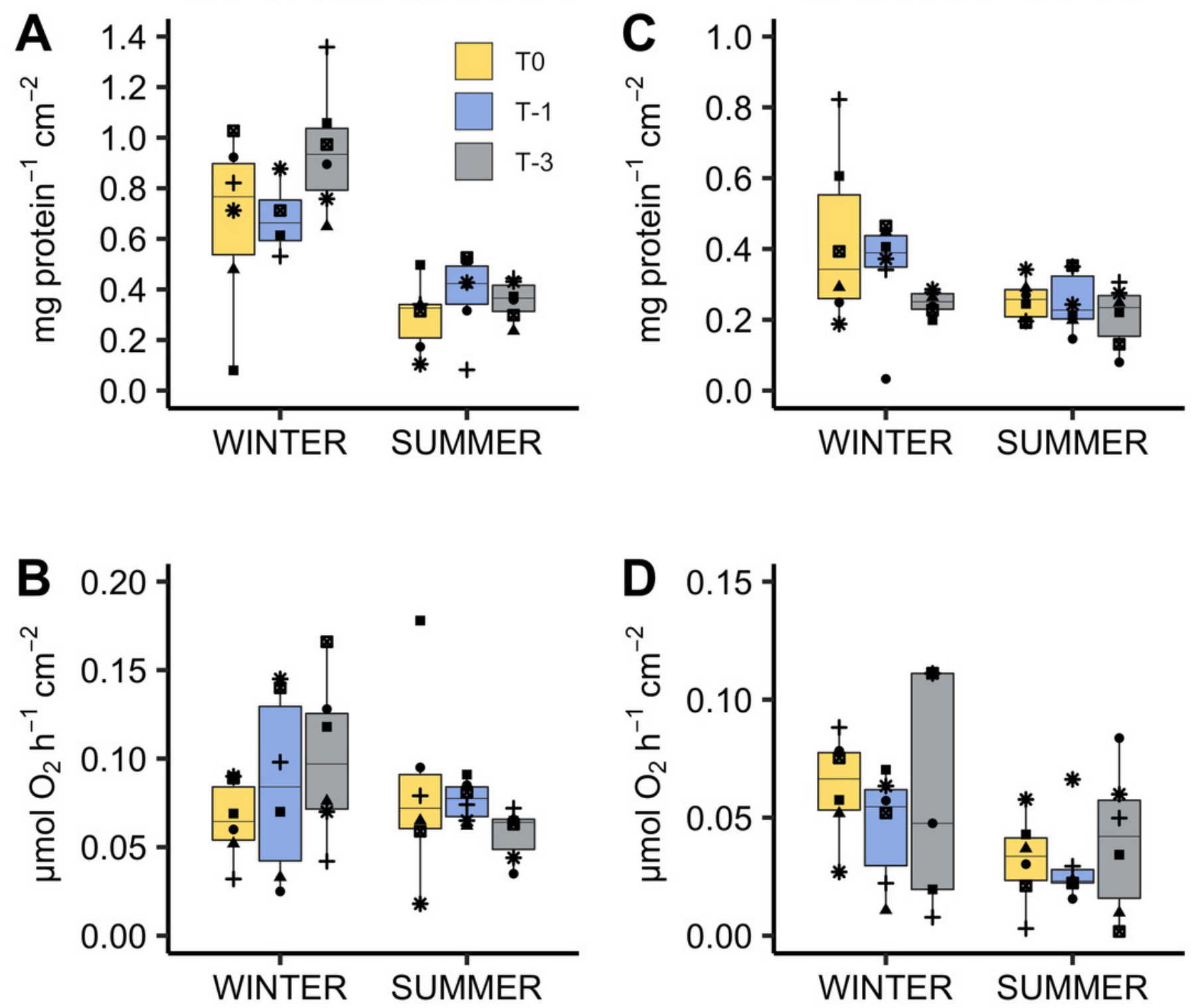


\section{Figure 4}

Figure 4 Thermal performance curve of maximum quantum yield of photosystem II $\left(F_{v} / F_{M}\right)$ of corals in Eilat.

Data are from published ex situ experiments including the current study (purple), Kruger et al., 2017 (yellow), Fine et al., 2013 (green), and Bellworthy and Fine 2017 (blue). Data points represent multiple species with thermal incubation times between 16 and 47 days $(n=149)$. The thick black line indicates the smoothed conditional mean with $99 \%$ confidence intervals (grey border). Dotted vertical lines indicate annual average minimum (Tmin) and maximum (Tmax) reef seawater temperatures in Eilat taken from the current paper and Bellworthy and Fine (2017) respectively. 


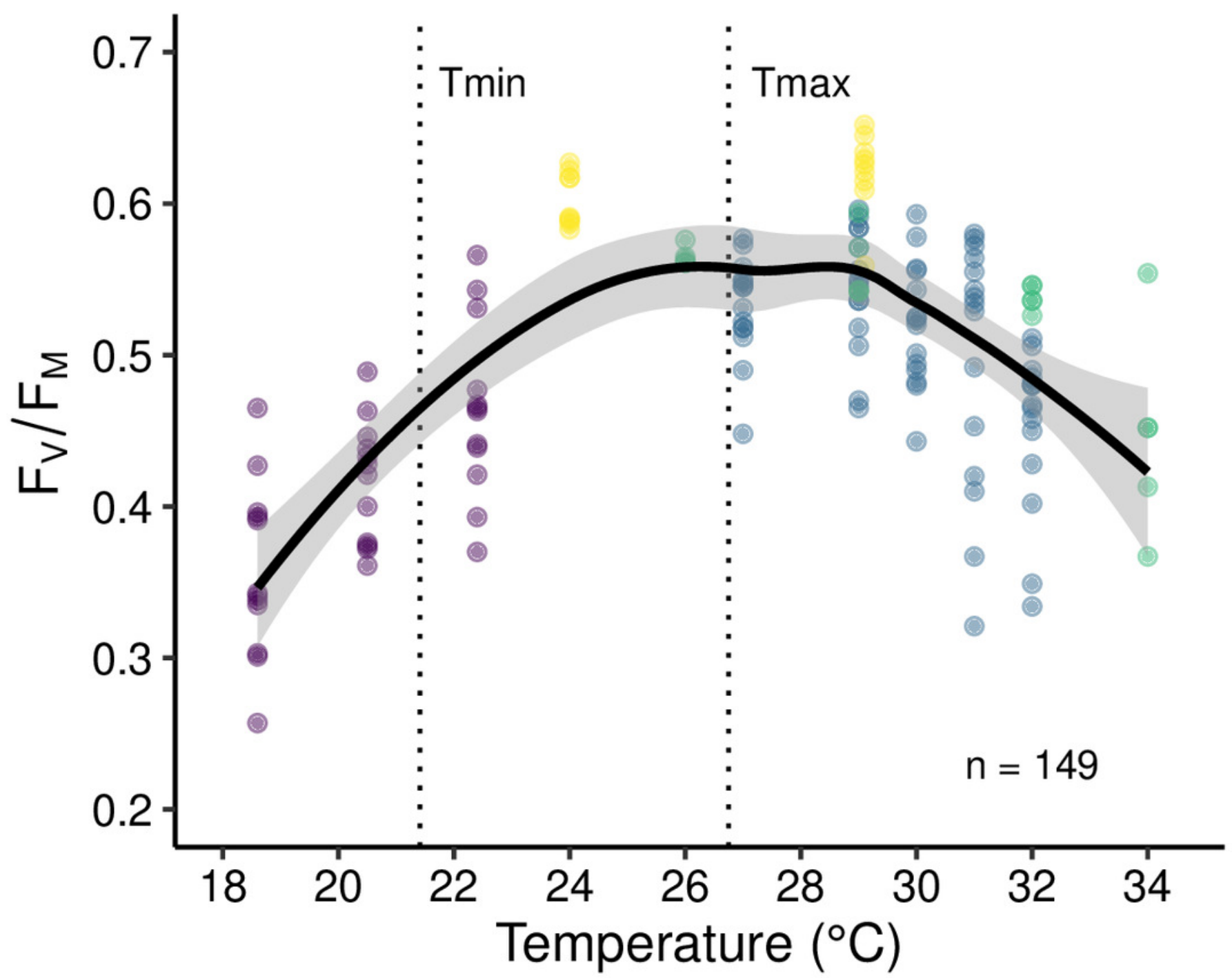

